\title{
Energy sources in low intake supplements on the productive and reproductive performance of Zebu cows
}

\section{Fontes energéticas em suplementos de baixo consumo sobre o desempenho produtivo e reprodutivo de vacas zebuínas}

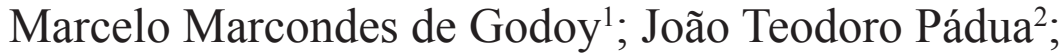 \\ João Restle ${ }^{3}$; Regis Luis Missio ${ }^{4 *}$
}

\begin{abstract}
The aim of this study was to evaluate the productive and reproductive performance of primiparous zebu cows supplemented on Brachiaria brizantha cv. Marandu with supplements of low intake composed of different energy sources in the postpartum period. Sixty cow-calf pairs were divided into three treatments, a standard mineral salt supplement, a supplement based on ground corn and another containing protected fat, under the same conditions of pasture. The cows had an average initial age of 36 months and $295.9 \pm 20 \mathrm{~kg}$ of initial body weight. The evaluation period lasted from November 2006 to May 2007, the 24 days after delivery until weaning of calves to 192 days of age. Cows fed the supplement based on ground corn $\left(351 \mathrm{~g} \mathrm{day}^{-1}\right)$ and protected fat $\left(357 \mathrm{~g} \mathrm{day}^{-1}\right)$ showed a similar increase in body weight, which was higher in relation cows fed with the mineral mixture $\left(179 \mathrm{~g} \mathrm{day}^{-1}\right)$. Mineral mixture supplementation resulted in body condition score loss of cows between 80 and 136 days after calving. Cows fed energy supplements of low consumption produced more milk, weaned heavier calves and showed higher pregnancy rate than those fed only with the mineral mixture. The use of $3 \%$ calcium salts of fatty acids in energy supplements of low consumption did not alter the productive and reproductive performance of primiparous Zebu cows.
\end{abstract}

Key words: Calcium soaps of fatty acids, milk production, Nellore, pregnancy rate

\section{Resumo}

Avaliaram-se diferentes fontes energéticas em suplementos de baixo consumo sobre o desempenho produtivo e reprodutivo de vacas primíparas zebuínas manejadas em Brachiaria brizantha cv. Marandu. Foram utilizados 60 pares de vacas/bezerros (as) distribuídos em três tratamentos, suplemento padrão a base de mistura mineral, suplemento com grão de milho moído e suplemento contendo gordura protegida, sob as mesmas condições de pasto. As vacas apresentavam idade média inicial de 36 meses e $295.9 \pm 20 \mathrm{~kg}$ de peso corporal médio inicial. O período de avaliação se estendeu de novembro de 2006 até maio de 2007, dos 24 dias após o parto até o desmame dos bezerros (as) aos 192 dias de idade. Vacas alimentadas com suplemento à base de grão de milho moído $\left(351 \mathrm{~g} \mathrm{dia}^{-1}\right)$ e gordura protegida $(357 \mathrm{~g}$ $\left.\mathrm{dia}^{-1}\right)$ apresentaram semelhante acréscimo de peso corporal, o qual foi superior às vacas alimentadas com mistura mineral $\left(179 \mathrm{~g} \mathrm{dia}^{-1}\right)$. A suplementação com mistura mineral resultou em perda de escore corporal das vacas entre 80 e 136 dias após o parto. Vacas alimentadas com suplementos energéticos de baixo consumo apresentaram maior produção de leite, desmamaram bezerros mais pesados e

1 Prof., Instituto Federal de Educação, Ciência e Tecnologia Goiano, Ceres, GO, Brasil. E-mail: marcondes.godoy@hotmail.com Prof., Depto de Produção Animal, UFG, Goiânia, GO, Brasil. E-mail: teodoro@vet.ufg.br

Bolsista PVNS CAPES, Fundação Universidade Federal do Tocantins, UFT, Araguaína, TO, Brasil. E-mail: jorestle@terra.com.br

4 Prof., Dept ${ }^{\circ}$ de Agronomia, Universidade Tecnológica Federal do Paraná, UTFPR, Pato Branco, PR, Brasil. E-mail: regisluismissio@gmail.com

* Author for correpondence 
apresentaram maior taxa de prenhez que aquelas alimentadas com mistura mineral. A utilização de $3 \%$ de sabões de cálcio de ácidos graxos em suplementos energéticos de baixo consumo não alterara o desempenho produtivo e reprodutivo de vacas primíparas zebuínas.

Palavras-chave: Nelore, percentagem de prenhez, produção de leite, sabões de cálcio de ácidos graxos

\section{Introduction}

Increased beef production, which is necessary to meet the demand for animal protein, is directly related to the reproductive management of herds. Among the factors affecting reproduction, nutrition management has the greatest impact, and energy is the primary nutrient required for female reproduction (HESS; MOSS; RULE, 2008). It has been observed that improved feeding conditions pre-partum and post-partum promote satisfactory increases in beef cow reproductive rates (WRIGHT et al., 1992).

However, for most breeding herds, mineral supplementation is commonly the only available nutrient source in addition to pasture. This condition, the limited quality of most tropical grasses and inadequate pasture management fails to meet the nutrition demand of breeding females, which induces a negative energy balance postpartum. Under this condition, the LH pulse frequency; dominant follicle growth rate and diameter; IGF-I concentration; glucose; and insulin are reduced, and $\mathrm{GH}$, as well as specific blood metabolites, increase, which decreases body condition and increases the percentage of anoestrus cows (HESS et al., 2005).

This period can be minimised by complementing pasture feeding with nutrition supplements. However, multiple supplements cannot be used, given the cost of food, transportation and distribution. Thus, formulating supplements in which the animal controls its intake may reduce the cost of labour and transportation, as well as avoid supplement dependence and the negative associative effect between forage and energy supplements. However, for such an outcome, feed type and nutrition characteristics and use are crucial. Fat is an important ingredient because it provides $2.25 \%$ more energy than carbohydrates. Furthermore, fatty acid calcium soaps support positive reproductive performance, regardless of the caloric effects (FUNSTON, 2004; HESS; MOSS; RULE, 2008; ARANA; VELÁSQUEZ, 2012).

This study was aimed at evaluating different energy sources for low intake supplements and determining their effects on the productive and reproductive performance of primiparous Zebu cows managed in a Brachiaria brizantha cv. Marandu pasture.

\section{Materials and Methods}

The research was conducted between November 2006 to May 2007 at a commercial farm located in the municipality of Piraquê (latitude $06^{\circ} 46^{\prime} 25^{\prime \prime}$ south and longitude $48^{\circ} 17^{\prime} 49^{\prime \prime}$ west), north of the state of Tocantins, Brazil. Sixty primiparous cows and calves were used; 48 were $1 / 2$ Guzera x $1 / 2$ Nellore cows mated with a Limousin bull, and 12 were Nellore cows mated with a Nellore bull. The breeding season was from November to January 2005 (60 days). Cows presented at the beginning of the experimental test average age of 36 months and average body weight of $295.9 \pm 20 \mathrm{~kg}$. The cows were randomly selected (according to the genetic group) from a population of 400 primiparous cows calved in eight days interval. Prior to the experiment, the cows were managed on Brachiaria brizantha cv. Marandu with mineral supplementation. The experimental design was a randomised block, which considered the cow's genotype as a blocking criterion. The cows and calves were assigned to one of three treatments: standard supplement based on a mineral mixture, supplement with ground corn grain and supplement containing rumen-protected fat (Table 1). The adaptation period to the facilities, food and management was of $15 \mathrm{~d}$. 
Table 1. Supplement composition.

\begin{tabular}{lccc}
\hline \multirow{2}{*}{ Ingredients (\% dry matter) } & \multicolumn{3}{c}{ Treatments (supplements) } \\
\cline { 2 - 4 } & Standard & Ground corn & Rumen-protected fat \\
\hline Mineral mixture $^{1}$ & 100.0 & 84.3 & 89.5 \\
Urea & -- & 3.9 & 3.9 \\
Ground corn grain & -- & 11.8 & 3.6 \\
Megalac-E $^{2}$ & -- & -- & 3.0 \\
Crude protein & -- & 12.22 & 11.52 \\
Total digestible nutrients & -- & 10.33 & 11.14 \\
\hline
\end{tabular}

${ }^{1}$ Composition (g/kg): Ca: 162.5; P: 68.8; S: 16.4; Na: 102.5; Mg: 24; Co: 0.08; Cu: 1.6; I: 0.07; Mn: 1.6; and Zn: 42.2 .

${ }^{2}$ Church and Dwight Company.

Source: Elaboration of the authors.

The experimental units (cows and calves) were managed under a continuous stocking system $(1.3$ AU/ha mean at experiment initiation) in three 14.5-ha paddocks of Brachiaria brizantha cv. Marandu with similar pasture conditions (Figure 1) and equipped with troughs. Animals had natural shade and water available. Prior to the experiment, the pasture was standardised through grazing management.

Figure 1. Mean leaf blade mass in the Brachiaria brizantha cv. Marandu pasture as a function of treatment and experimental period.

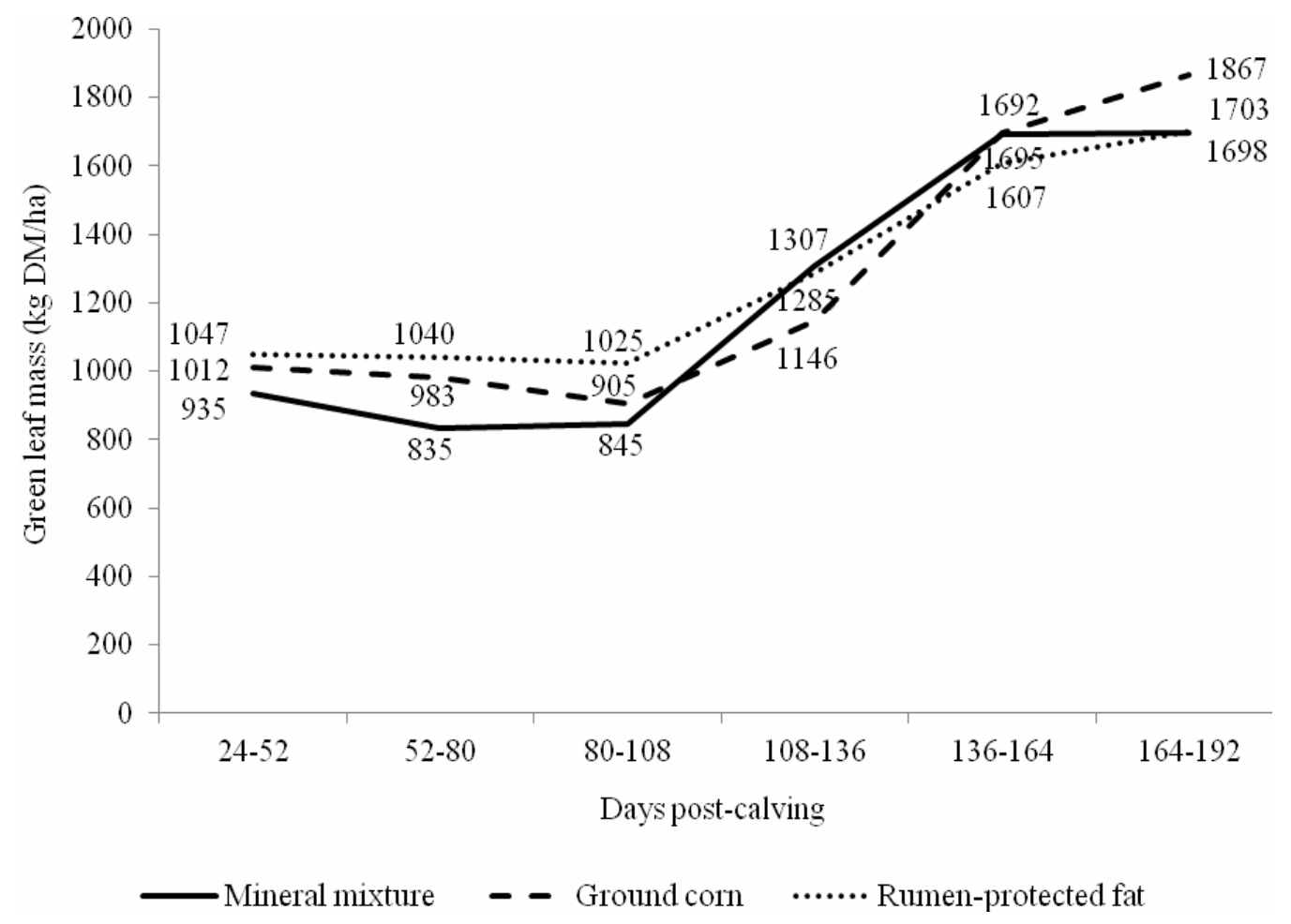

Source: Elaboration of the authors. 
The mass of leaf blades was evaluated when the experiment began and every 28 days using samples collected from the sites at medium height of the forage canopy. All forage included within the perimeter of the rising plate $\left(0.5 \mathrm{~m}^{2}\right)$ was collected at soil level. The green leaves were separated from the other structural components of the pasture (stem and dead material), weighed, pre-dried in a forced air oven at $55^{\circ} \mathrm{C}$ for 72 hours, ground in a Willey mill with a 1-mm sieve and analysed for dry matter and crude protein (AOAC, 1995), neutral detergent fiber (VAN SOEST; ROBERTSON; LEWIS, 1991) and total digestible nutrients (TDN) (CAPELLE; VALADARES FILHO; SILVA, 2001), wherein TDN $=83.79-0.4171 *$ neutral detergent fiber (Table 2).

Table 2. Leaf composition of the Brachiaria grass throughout the experiment according to treatment.

\begin{tabular}{|c|c|c|c|c|c|c|}
\hline \multirow{2}{*}{ Supplements } & \multicolumn{6}{|c|}{ Days post-calving } \\
\hline & $24-52$ & $52-80$ & $80-108$ & $108-136$ & $136-164$ & $164-192$ \\
\hline \multicolumn{7}{|c|}{ Dry matter, $\%$ fresh matter } \\
\hline Mineral mixture & 28.2 & 28.4 & 27.9 & 32.2 & 30.8 & 24.2 \\
\hline Ground corn & 33.9 & 33.8 & 33.9 & 32.7 & 26.4 & 24.2 \\
\hline Rumen-protected fat & 33.5 & 33.8 & 32.8 & 31.2 & 28.2 & 24.8 \\
\hline \multicolumn{7}{|c|}{ Crude protein, $\%$ dry matter } \\
\hline Mineral mixture & 10.6 & 11.3 & 11.2 & 10.9 & 8.8 & 7.2 \\
\hline Ground corn & 8.4 & 8.3 & 8.5 & 8.8 & 7.6 & 7.5 \\
\hline Rumen-protected fat & 9.0 & 9.2 & 8.9 & 8.6 & 8.2 & 8.7 \\
\hline \multicolumn{7}{|c|}{ Neutral detergent fibre, $\%$ dry matter } \\
\hline Mineral mixture & 68.7 & 68.9 & 68.5 & 67.3 & 69.6 & 71.8 \\
\hline Ground corn & 69.3 & 69.3 & 69.3 & 68.3 & 69.5 & 71.0 \\
\hline Rumen-protected fat & 70.2 & 70.5 & 70.0 & 68.0 & 69.0 & 69.7 \\
\hline \multicolumn{7}{|c|}{ Total digestible nutrients, $\%$ dry matter } \\
\hline Mineral mixture & 55.1 & 55.1 & 55.2 & 55.7 & 54.8 & 53.8 \\
\hline Ground corn & 54.9 & 54.9 & 54.9 & 55.3 & 54.8 & 54.2 \\
\hline Rumen-protected fat & 54.5 & 54.4 & 54.6 & 55.4 & 55.0 & 54.7 \\
\hline
\end{tabular}

Source: Elaboration of the authors.

The supplements were provided up to 192 days after calving when the calves were weaned. The supplements were provided in exposed feeders along rows $\left(0.5 \mathrm{~m}\right.$ animal $\left.{ }^{-1}\right)$, and feeder height $(1.3 \mathrm{~m})$ restricted the calves' supplement access. To maintain an ad libitum supplement supply, the feeders were monitored daily, and supplement intake was determined by weighing what was offered, as well as the orts.

The animals were weighed individually 24 days post-calving and every 28 days until weaning. When they were weighed, the cows were evaluated for a body condition score (average of three trained evaluators) on a scale from 1 (very thin) to 5 (very fat). For each treatment, 10 cows were assessed for milk production 24 days after calving and every 28 days until weaning through a direct method (milking). To milk the cows, they were separated from their calves the day before milking and released in an attached paddock. At approximately $6 \mathrm{pm}$, the cows and calves were taken to the management centre, and the calf was allowed to feed for 30 minutes, which is sufficient to empty the udder. Subsequently, the calves were separated from the cows and contained in the management centre while the cows were released in a paddock with pasture and water. At 6 am the following day, the cows were milked after previous intramuscular 
injection of $3 \mathrm{ml}$ of oxytocin and washing the udder; the volume milked was adjusted for 24-hour milk production (RESTLE et al., 2003).

Twenty-eight days after the experiment began, one Limousin bull fit for reproduction was placed in each paddock with a bull to cow ratio 1:20. Sixty days after experiment completion, pregnancy was detected by rectal palpation by a trained professional. Calf production ( $\mathrm{kg} 100 \mathrm{~kg}^{-1}$ cow body weight) at weaning was calculated using the quotient between the cow and calf body weight 192 days post-calving multiplied by 100 .

The data were analysed through analysis of variance and polynomial regression (performed on the adjusted data). The regression equations were analysed using the parallelism test and identity of the curves (LITTEL et al., 2006); when necessary, the means were compared using Tukey's test, except for the pregnancy rate, which was analysed using the Chi-square test $\left(\mathrm{X}^{2}\right)$. The initial body weight and body condition score for the cows, as well as calf gender, were considered covariates and were removed from the model when they were nonsignificant.

For the cow-related variables, we used the following mathematical model: $\mathrm{g}_{\mathrm{ijklm}}=\mu+\pi \mathrm{i}+\mathrm{t}_{\mathrm{j}}$ $+(\pi \mathrm{t})_{\mathrm{ij}}+\mathrm{b}_{\mathrm{k}+}(\mathrm{tb})_{\mathrm{jk}}+£_{1}+\alpha_{\mathrm{m}}+\mathrm{e}_{\mathrm{ijk} k \mathrm{~m}}$, where $\mathrm{g}_{\mathrm{ijklm}}=$ dependent variable; $\mu=$ overall mean; $\pi \mathrm{i}=$ block effect; $\mathrm{t}_{\mathrm{j}}=$ supplement effect; $(\pi \mathrm{t})_{\mathrm{ij}}=$ interaction between block $\mathrm{i}$ and treatment $\mathrm{j} ; \mathrm{b}_{\mathrm{k}}=$ time $\mathrm{k}$ effect; $(\mathrm{tb})_{\mathrm{jk}}=$ interaction between treatment $\mathrm{j}$ and time $\mathrm{k} ; £_{1}=$ covariate 1 effect (initial body score); $\alpha_{\mathrm{m}}=$ covariate $\mathrm{m}$ effect (initial body weight); and $\mathrm{e}_{\mathrm{ijklm}}=$ residual experimental error.

For the calf-related variables, the mathematical model was $\mathrm{g}_{\mathrm{ijklm}}=\mu+\pi_{\mathrm{i}}+\mathrm{t}_{\mathrm{j}}+(\pi \mathrm{t})_{\mathrm{ij}}+\mathrm{b}_{\mathrm{k}+}(\mathrm{tb})_{\mathrm{jk}}+£_{1}$ $+\alpha_{\mathrm{m}}+\mathrm{e}_{\mathrm{ijklm}}$, where $\mathrm{g}_{\mathrm{ijklm}}=$ dependent variable; $\mu=$ overall mean; $\pi \mathrm{i}=$ block $\mathrm{i}$ effect; $\mathrm{t}_{\mathrm{j}}=$ supplement $\mathrm{j}$ effect; $(\pi \mathrm{t})_{\mathrm{ij}}=$ interaction between block $\mathrm{i}$ and treatment $\mathrm{j} ; \mathrm{b}_{\mathrm{k}}=$ time $\mathrm{k}$ effect; $(\mathrm{tb})_{\mathrm{jk}}=$ interaction between treatment $\mathrm{j}$ and time $\mathrm{k} ; £_{1}=$ covariate 1 effect (gender); $\alpha_{\mathrm{m}}=$ covariate $\mathrm{m}$ effect (initial body weight); and $\mathrm{e}_{\mathrm{ijklm}}=$ residual experimental error.
Pregnancy rate and calf production were evaluated using the following model: $\mathrm{g}_{\mathrm{ij}}=\mu+\pi_{\mathrm{i}}+$ $\mathrm{t}_{\mathrm{j}}+\mathrm{e}_{\mathrm{ijk}}$, where: $\mathrm{g}_{\mathrm{ij}}=$ dependent variable; $\mu=$ overall mean; $\pi_{i=}$ block $\mathrm{i}$ effect; $\mathrm{t}_{\mathrm{j}}=$ treatment $\mathrm{j}$ effect; and $\mathrm{e}_{\mathrm{ijk}}=$ residual experimental error. For regression analysis, the model was $\mathrm{g}_{\mathrm{ij}}=\mathrm{b}_{0}+\mathrm{b}_{1} \mathrm{X}_{\mathrm{i}}+\mathrm{b}_{2} \mathrm{X}_{\mathrm{i}}^{2}+\mathrm{b}_{3}$ $\mathrm{X}_{\mathrm{i}}^{3}+\mathrm{a}_{\mathrm{j}+} \varepsilon_{\mathrm{ij}}$, where $\mathrm{g}_{\mathrm{ij}}=$ dependent variables; $\mathrm{b}$ 's $=$ regression coefficients; $\mathrm{X}_{\mathrm{i}}=$ independent variables; $\mathrm{a}_{\mathrm{j}}=$ regression deviation; and $\varepsilon_{\mathrm{ij}}=$ random residual error.

\section{Results and Discussion}

Variation in the cows' body weight was independent of measurement time (Figure 2). The cows fed ground corn supplement and rumenprotected fat had similar body weights throughout the experiment, which were higher in relation the body weight of cows fed the mineral mixture. The average daily weight gain was of 307,312 and $156 \mathrm{~g} \mathrm{day}^{-1}$ for cows fed supplements containing ground corn grain, rumen-protected fat and mineral mixture, respectively. The variation in cow body weight and body weight gain was associated with complementary nutrition through the supplement to pasture, the mean intake of the supplements containing ground corn grain, rumen-protected fat and mineral mixture were 358, 353 and $179 \mathrm{~g}$ day $^{-1}$, respectively. Despite the low consumption of supplements, should be considered the benefits of supplementation on fiber digestibility and forage intake (PAULINO; DETMANN; VALADARES FILHO, 2006), which may have potentiated the effect of ground corn and rumen-protected fat based supplements on weight gain of cows. In a way, the results were consistent with those reported in the literature because greater nutrient intake postcalving supports a greater increase in body weight and improved conception rates, furthermore, the effect of feeding level was more accentuated in cows with a reduced body condition (WRIGHT et al., 1992; LOBATO; MENEGAZ; PEREIRA, 2010). 
Figure 2. Body weight according to days post-calving for primiparous Zebu cows grazing Brachiaria grass pasture and supplemented with low intake supplements.

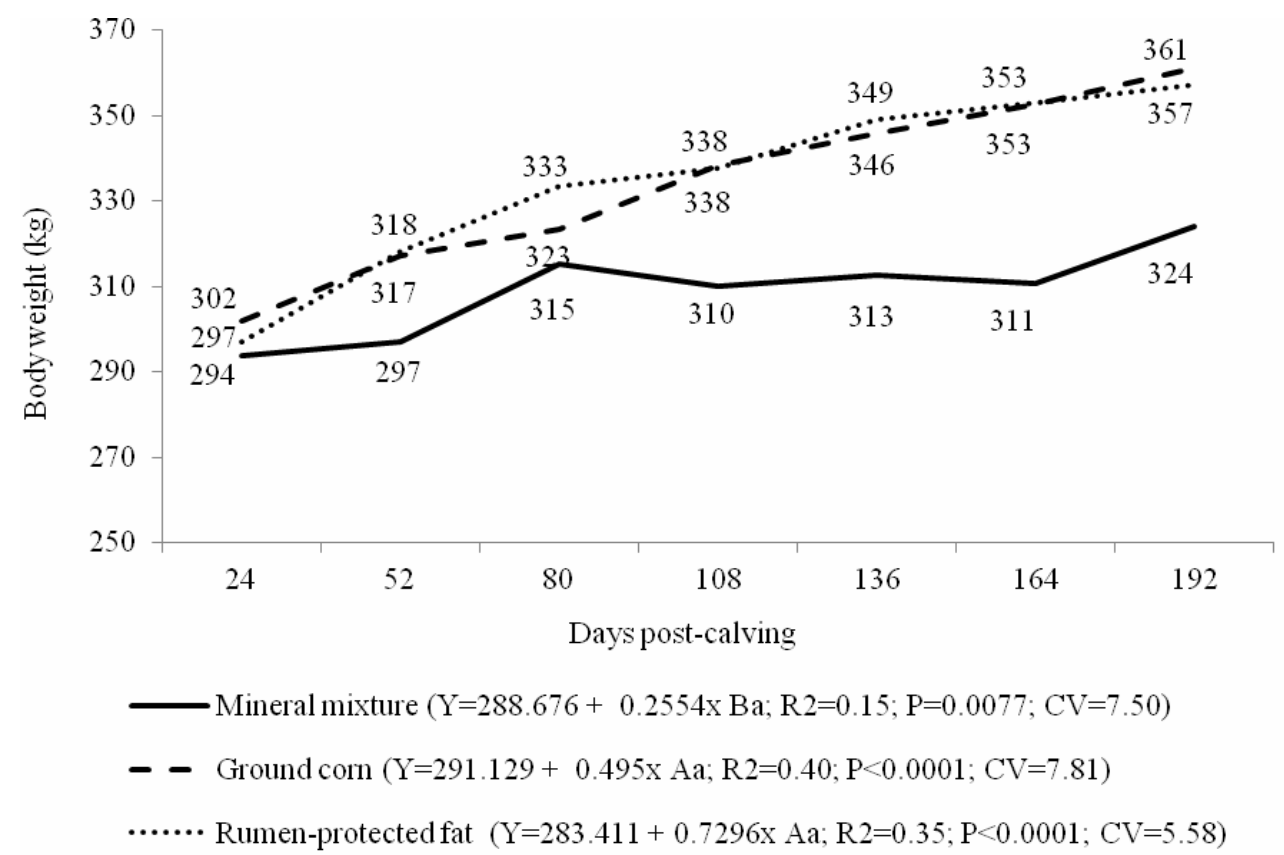

Regression equations followed by similar capital letters are identical and parallel $(\mathrm{P}<0.05)$, respectively.

Source: Elaboration of the authors.

The similar weight gain for cows fed ground corn or rumen-protected fat was associated with a similar capacity for complementing pasture nutrients because they are isoproteic and isoenergetic. According to Mattos, Staples and Thatcher (2000), fat addition to a beef cow diet is primarily to increase the diet's energy density, which improves energy balance and increases milk production. However, changes in the body weight of lactating cows supplemented with rumen-protected fat are variable and most likely associated with levels supplied. Moreover, the animal's response to fat supplementation may be more pronounced in thin animals, which is also dependent on supplement duration, available nutrients in the basal diet, animal age and fat type (FUNSTON, 2004; HESS; MOSS; RULE, 2008).

For cow body condition, an interaction was observed between the supplements and time the body condition was scored (Figure 3). Thus, the supply of low intake energy supplements supported body condition maintenance from calving until weaning without a significant effect of the energy sources for this characteristic. According to Silveira et al. (2012) supplementation with protected fat during the period of milk production of beef cows helps in maintaining a positive energy balance, which may result in lower mobilization of body reserves, reducing the drop in body condition. In contrast, in cows fed with mineral mixture, the body condition showed quadratic variation as a function of days post-calving, with lowest body condition score estimated for 138 days after parturition. The reduced body condition after 80 days of lactation in cows fed the mineral mixture may have been associated with the increased nutrition demand of the cows due to the increase in body weight of calves and their demand for milk, as proposed by NRC (1996). Remember that the body condition of cattle may decrease while there is an increase of body weight, depending on the bone and muscle growth at the expense of body fat (NRC, 1996). 
Figure 3. Body condition score for primiparous Zebu cows grazing Brachiaria grass pasture with low intake supplements.

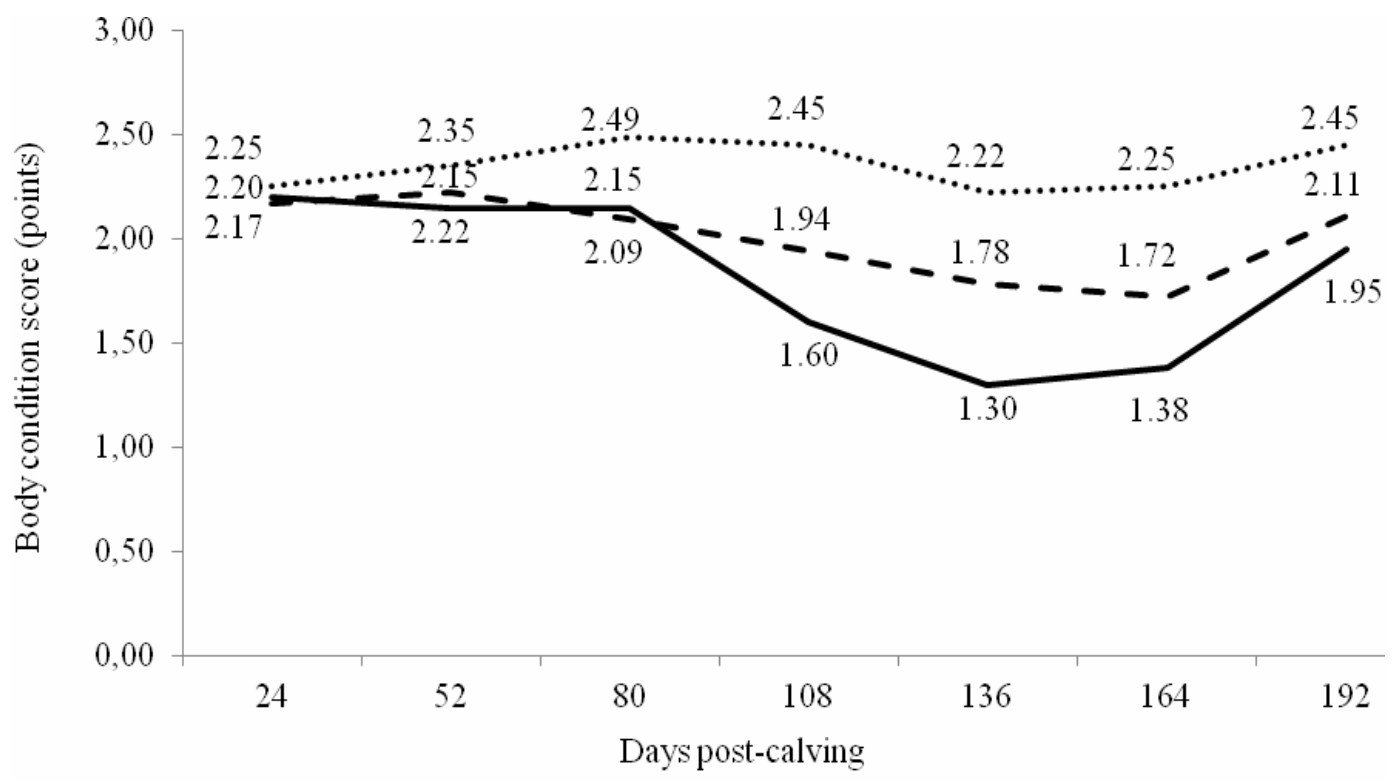

- Mineral mixture $(\mathrm{Y}=2.7651-0.017 \mathrm{x}+0.0000607 \mathrm{x} 2 ; \mathrm{R} 2=0.21 ; \mathrm{P}=0.0004 ; \mathrm{CV}=32.09)$

- - Ground corn $(\mathrm{Y}=2.47 ; \mathrm{P}=0.0726 ; \mathrm{CV}=22.54)$

…. Rumen-protected fat $(\mathrm{Y}=2.38 ; \mathrm{R} 2=0.8100 ; \mathrm{CV}=21.01)$

Source: Elaboration of the authors.

Note that for all treatments throughout the experiment (Figure 3), the cow body condition was characterised as thin. This observation is important from the reproduction standpoint because maximum conception rates are observed for an intermediate body condition (SANTOS et al., 2009; ARANA; VELÁSQUEZ, 2012), which reflects a body condition score of 3 using the scale described above. The body condition of cows also affects the calf production because animals with moderate body conditions tend to produce more milk (BRAUNER et al., 2009).

Milk production varied independently as a function of the supplement used and the length of time in which it was measured (Figure 4). Accordingly, the supplements formulated with both energy sources supported greater milk production compared with the mineral mixture. Notably, for each supplement, milk production decreased linearly as a function of days post-calving, which is partially consistent with Restle et al. (2003). These authors observed that cows fed with greater nutrient support postpartum showed a quadratic variation in milk production as a function of days post-calving, whereas cows with low nutrient intake exhibited a linear decrease in milk production as a function of days post-calving.

For calf production (kg body weight $100 \mathrm{~kg}^{-1}$ exposed cow), the calves from cows fed energy supplements had a greater weight increase and were heavier at weaning compared with the calves from cows fed the mineral mixture-based supplements (Figure 5), which is associated with greater milk production. As a result, calf production at weaning was similar for cows fed energy supplements, which exceeded production from cows fed with the mineral 
mixture (Figure 6). Considering the cow pregnancy rates from the different treatments and offspring performance, calf production at the next weaning may be even more striking, given that the projected estimates for the mineral mixture, ground corn grain and rumen-protected fat treatments were 2.58, 42.1 and $63.1 \mathrm{~kg}$ weaned calves $100 \mathrm{~kg}^{-1}$ exposed cows, respectively.

Figure 4. Milk production from cows grazing Brachiaria grass pastures with low intake supplements.

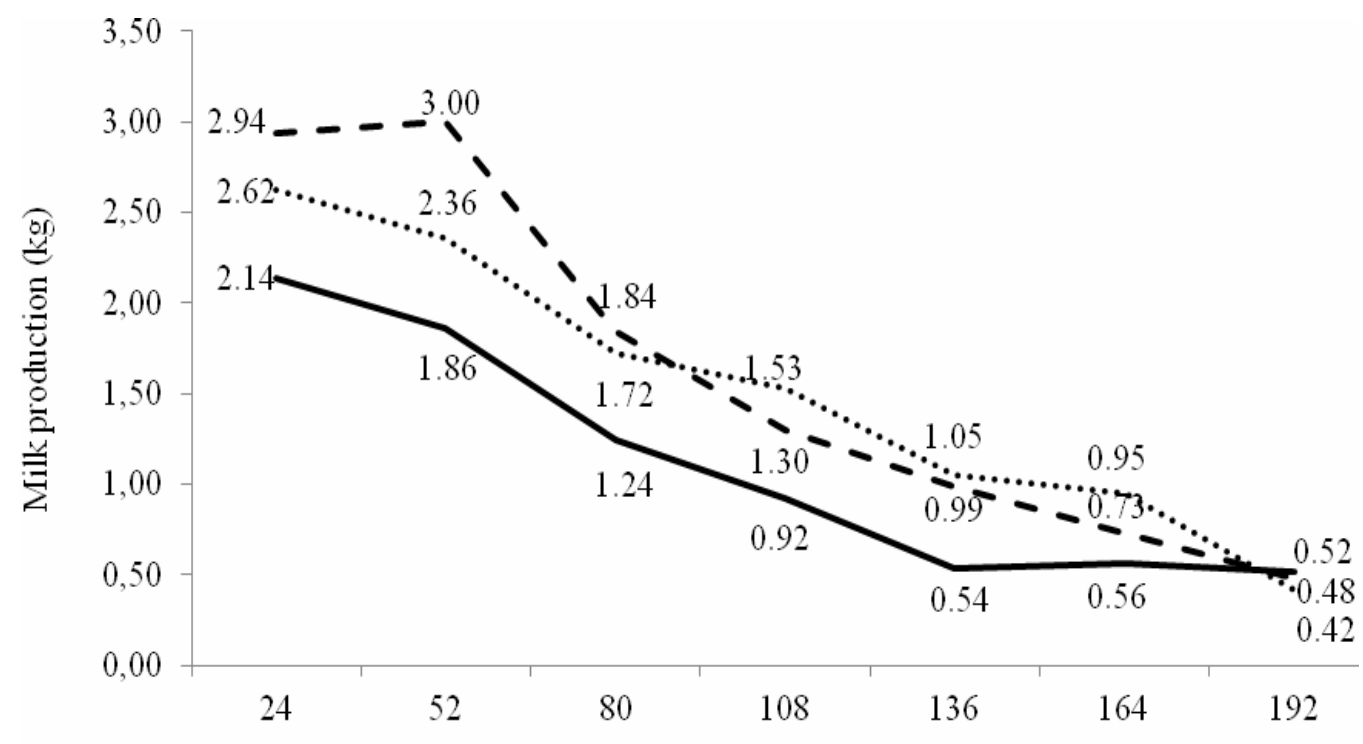

Days post-calving

$$
\begin{aligned}
& \text { Mineral mixture }(\mathrm{Y}=2.7897-0.02444 \mathrm{x} \mathrm{Ba} ; \mathrm{R} 2=0.98 ; \mathrm{P}=0.0026 ; \mathrm{CV}=10.62) \\
& \text { - } \text { - Ground corn }(\mathrm{Y}=3.8121-0.0274 \mathrm{x} \text { Aa; } \mathrm{R} 2=0.95 ; \mathrm{P}=0.035 ; \mathrm{CV}=17.64) \\
& \cdots \cdots . \text { Rumen-protected fat }(\mathrm{Y}=3.0111-0.0154 \mathrm{x} \text { Aa; } \mathrm{R} 2=0.98 ; \mathrm{P}=0.0001 ; \mathrm{CV}=8.60)
\end{aligned}
$$

Regression equations followed by similar capital letters are identical and parallel $(\mathrm{P}<0.05)$, respectively.

Source: Elaboration of the authors.

The results are consistent with the literature, wherein higher milk production, which is supported by a more nutritious diet, yields greater weight gain in the offspring and, consequently, results in greater calf body weight (RESTLE et al., 2004). The similarity for the increase in body weight from the energy supplements (Figure 5) can also be explained by milk production. These results are inconsistent which Espinoza et al. (1995), who observed higher calf body weight from cows supplemented with fatty acid calcium soaps, which was associated with higher milk production according to the authors. The supplements used by these authors were not isoenergetic, which may have favoured milk production in the cows supplemented with fat. 
Figure 5. Calf body weight from primiparous Zebu cows grazing Brachiaria grass pasture with low intake supplements.

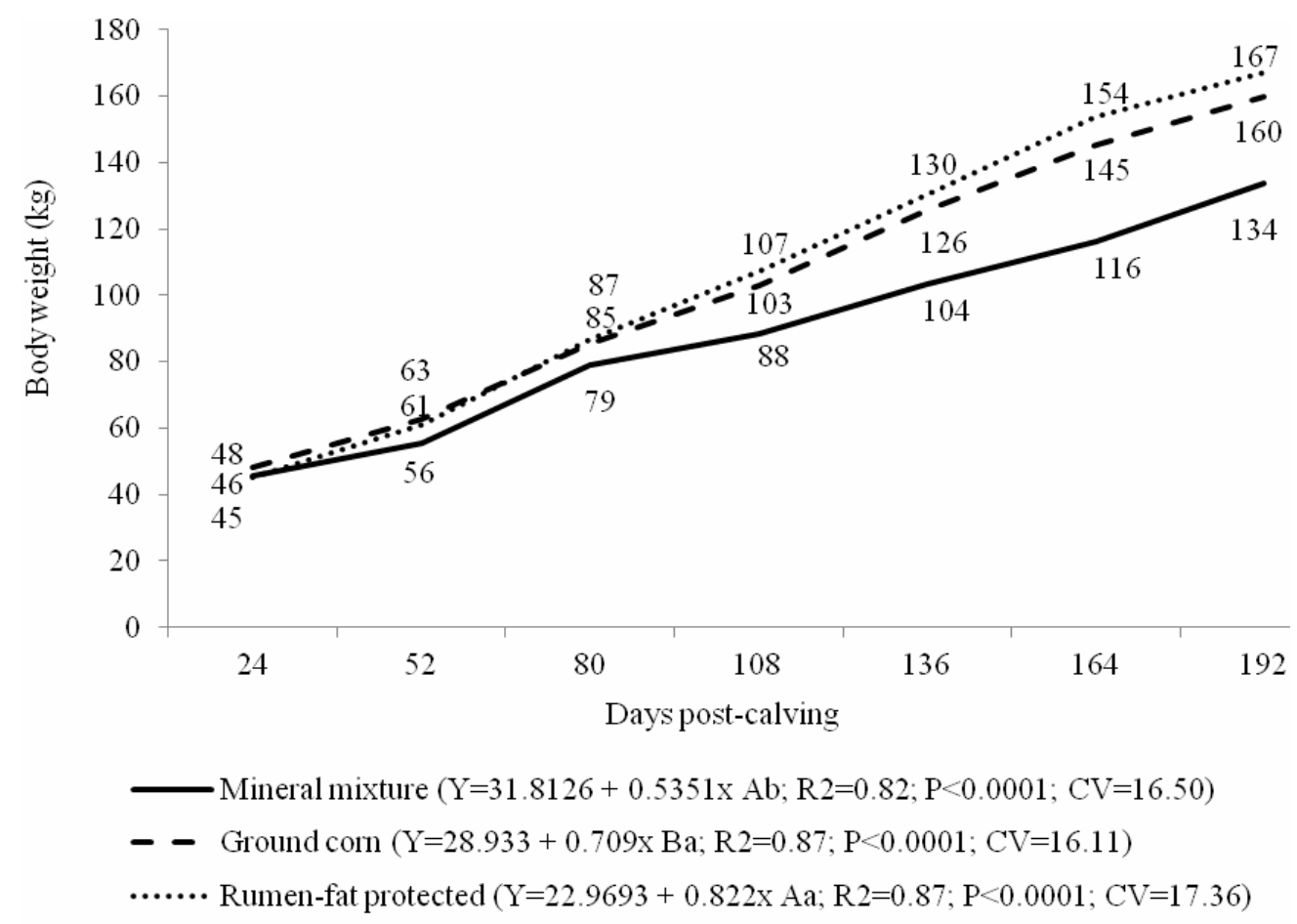

Regression equations followed by similar capital letters are identical and parallel $(\mathrm{P}<0.05)$, respectively.

Source: Elaboration of the authors.

The pregnancy rate was similar for the cows fed energy supplements, which was higher than the pregnancy rate of cows supplemented only with the mineral mixture (Figure 6). These results are consistent with the literature (WRIGHT et al., 1992) because higher energy intake post-calving especially in cows with a low body condition significantly increases the conception rate. This characteristic is strongly associated with greater weight gain and body condition recovery postcalving. In contrast, the results related to pregnancy rates of cows fed rumen-protected fat differed from the literature (HESS et al., 2005; LONG et al., 2007; LOPES et al., 2011), wherein a supply of fatty acid calcium soaps in beef cows was proposed to increase reproductive performance from the effect of fatty acid (linoleic and linolenic) on the ovary's functional capacity, which circulates progesterone and controls the life span of the corpus luteum. However, the increase in pregnancy rates based on use of protected fat in the diet of cows is not observed in all cases studied (JONES et al., 2008; MORIEL et al., 2012; PIZZUTI et al., 2012). It should be noted that, according to the level of inclusion of fat source in the supplement and the low consumption of supplement, occurred a reduced intake (10.2 g day $^{-1}$ ) of protected fat (Megalac-E), which possibly limited the animal response. 
Figure 6. Pregnancy rate and calf production in primiparous Zebu cows grazing Brachiaria grass with low intake supplements.

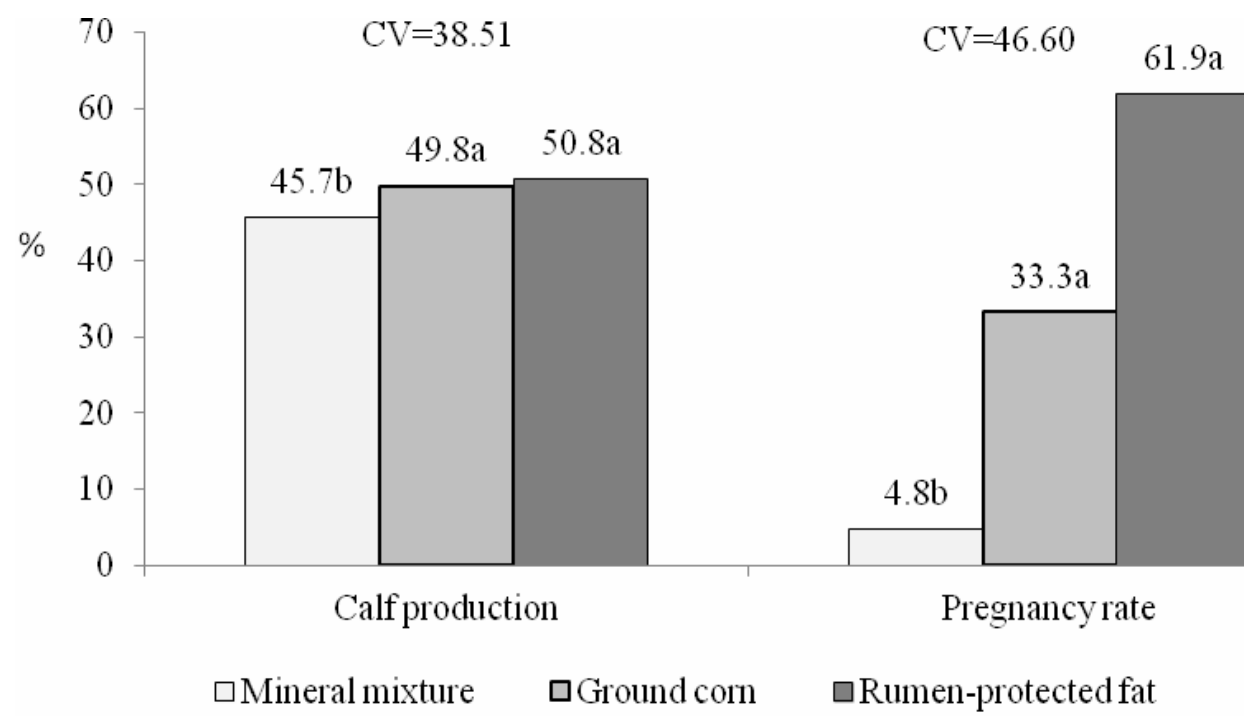

Means followed by different letter indicates a difference $(\mathrm{P}<0.05)$ among treatments.

Source: Elaboration of the authors.

\section{Conclusions}

Administering low intake energy supplements post-calving in primiparous Zebu cows with a low body condition managed on Brachiaria brizantha. cv Marandu pasture supports body condition maintenance and significantly increases calf production and pregnancy rate. However, the inclusion of $3 \%$ fatty acid calcium soaps in low intake energy supplements based on ground corn does not alter the productive and reproductive performance of primiparous Zebu cows managed in Marandu grass post-calving.

\section{References}

ARANA, D. G.; VELÁSQUEZ, L. F. U. Estrategias para mejorar la condición corporal postparto en vacas de carne. Biosalud, Manizales, v. 11, n. 1, p. 71-89, 2012.

ASSOCIATION OF OFFICIAL ANALYTICAL CHEMISTS - AOAC. Official methods of analysis. $16^{\text {th }}$ ed. Arlington: AOAC International, 1995, $1025 \mathrm{p}$.

BRAUNER, C. C.; PIMENTEL, M. A.; LEMES, J. S.; PIMENTEL, C. A.; MORAES, J. C. F. Desempenho reprodutivo pós-parto de vacas de corte submetidas a indução/sincronização de cio. Revista Brasileira de Zootecnia, Viçosa, MG, v. 38, n. 1, p. 99-103, 2009.

CAPELLE, E. R.; VALADARES FILHO, S. C.; SILVA, J. F. C. Estimativas do valor energético a partir de características químicas e bromatológicas dos alimentos. Revista Brasileira de Zootecnia, Viçosa, MG, v. 30, n. 6, p. 1837-1856, 2001.

ESPINOZA， J. L.; RAMIREZ-GODINEZ, J. A.; JIMENEZ, J. A.; FLORES, A. Effects of calcium soaps of fatty acids on postpartum reproductive activity in beef cows and growth of calves. Journal of Animal Science, Champaign, v. 73, n. 10, p. 2888-2892, 1995.

FUNSTON, R. N. Fat supplementation and reproduction in beef females. Journal of Animal Science, Champaign, v. 82 , n. 13, p. 154-161, 2004. Supplement.

HESS, B. W.; LAKE, S. L.; SCHOLLJEGERDES, E. J.; WESTON, T. R.; NAVIGIHUGU, V.; MOLLE, J. D. C.; MOSS, G. E. Nutritional controls of beef cow reproduction. Journal of Animal Science, Champaign, v. 83, n. 13, p. 90-106, 2005.

HESS, B. W.; MOSS, G. E.; RULE, D. C. A decade of developments in the area of fat supplementation research with beef cattle and sheep. Journal of Animal Science, Champaign, v. 86, n. 14, p. 188-204, 2008. 
JONES, B.; FISH, R. D.; MARTIN, A.; DUFF, G. C.; AX, R. L. Case study: effects of supplemental linoleic and linolenic acids on reproduction in Holstein cows. Professional Animal Scientist, Champaign, v. 24, n. 5, p. 500-505, 2008.

LITTEL, R. C.; MILLIKEN, G. A.; STROUP, W. W.; RUSSEL, D. W.; OLIVER, S. Sas for mixed models. $2^{\text {th }}$ ed. Cary: SAS Institute, 2006. 813 p.

LOBATO, J. F. P.; MENEGAZ, A. L.; PEREIRA, A. C. G. Pre and post-calving forage systems and reproductive performance of primiparous cows. Revista Brasileira de Zootecnia, Viçosa, MG, v. 39, n. 9, p. 2081-2090, 2010.

LONG, N. M.; HILL, G. M.; BAKER, J. F.; GRAVES, W. M.; FROETSCHEL, M. A.; KEISLER, D. H.; MULLINIX JR, B. G. Reproductive performance of beef heifers supplemented with corn gluten feed and rumenprotected fat before breeding. Professional Animal Scientist, Champaign, v. 23, n. 4, p. 316-324, 2007.

LOPES, C. N.; COOKE, R. F.; REIS, M. M.; PERES, R. F. G.; VASCONCELOS, J. L. M. Strategic supplementation of calcium salts of polyunsaturated fatty acids to enhance reproductive performance of Bos indicus beef cows. Journal of Animal Science, Champaign, v. 89, n. 10, p. 3116-3124, 2011.

MATTOS, R.; STAPLES, C. R.; THATCHER, W. W. Effects of dietary fatty acids on reproduction in ruminants. Reviews of Reproduction, London, v. 5, n. 1, p. $38-45,2000$.

MORIEL, P.; GONÇALVES, E. P.; CAPPELLOZZA, B. I.; NAYIGIHUGU, V.; BLOCK, E.; HESS, B. W. Plasma fatty acids and reproductive performance of lactating beef cows fed rumenprotected fat. Professional Animal Scientist, Champaign, v. 28, n. 1, p. 89-96, 2012.

NATIONAL RESEARCH COUNCIL - NRC. Nutrients requirements of beef cattle. $7^{\text {th }}$ ed. Washington, D.C.: National Academy of Sciences, 1996. 242 p.

PAULINO, M. F.; DETMANN, E.; VALADARES FILHO, S. C. Suplementação animal em pasto: energética ou protéica? In: SIMPÓSIO SOBRE MANEJO ESTRATÉGICO DA PASTAGEM, 3., 2006, Viçosa, MG. Anais... Viçosa, MG: SIMFOR, 2006. p. 359-392.
PIZZUTI, L. A. D.; ALVES FILHO, D. C.; BRONDANI, I. L.; RESTLE, J.; FREITAS, L. da. S.; ARGENTA, F. M.; MACHADO, D. S.; CARDOSO, G. S. C. Development and reproductive performance of beef heifers supplemented with brown rice meal and/or protected fat on temperate grasslands. Revista Brasileira de Zootecnia, Viçosa, MG, v. 41, n. 10, p. 2263-2271, 2012.

RESTLE, J.; PACHECO, P. S.; PASCOAL, L. L.; PÁDUA, J. T.; MOLETTA, L.; FREITAS, A. K. de; LEITE, D. T. Efeito da pastagem, da produção e da composição do leite no desempenho de bezerros de diferentes grupos genéticos. Revista Brasileira de Zootecnia, Viçosa, MG, v. 33, n. 3, p. 691-703, 2004.

RESTLE, J.; PACHECO, P. S.; MOLETTA, J. L.; BRONDANI, I. L.; CERDÓTES, L. Grupo genético e nível de nutricional pós-parto na produção e composição do leite de vacas de corte. Revista Brasileira de Zootecnia, Viçosa, MG, v. 32, n. 3, p. 585-597, 2003.

SANTOS, S. A.; ABREU, U. G. P. de; SOUZA, G. da S.; CATTO, J. B. Condição corporal, variação de peso e desempenho reprodutivo de vacas de cria em pastagem nativa no Pantanal. Revista Brasileira de Zootecnia, Viçosa, MG, v. 38, n. 2, p. 354-360, 2009.

SILVEIRA, M. F.; RESTLE, J.; MENEZES, L. F. G.; BRONDANI, I. L.; NÖRNBERG, J. L.; CALLEGARO, A. M. Metabólitos sanguíneos de vacas de corte suplementadas ou não com sais de cálcio de ácidos graxos durante o período pré e/ou pós-parto. Arquivo Brasileiro de Medicina Veterinária e Zootecnia, Belo Horizonte, v. 64, n. 6, p. 1418-1426, 2012.

VAN SOEST, P. J.; ROBERTSON, J. B.; LEWIS, B. A. Methods for dietary fiber, neutral detergent fiber, and nonstarch polyssacarides in relation to animal nutrition. Journal of Animal Science, Champaign, v. 74, n. 10, p. 3583-3597, 1991.

WRIGHT, I. A.; RHIND, S. M.; WHYTE, T. K.; SMITH, A. J. Effects of body condition at calving and feeding level after calving on LH profiles and the duration of the post-partum anoestrous period in beef cows. Animal Production, Melbourne, v. 55, n. 1, p. 41-46, 1992. 
